\title{
The Frequency of Winter Sleep Interruptions in Two Species of Bats Hibernating in Limestone Tunnels
}

\author{
CZESTOSC PRZERYWANIA SNU ZIMOWEGO DWOCH GATUNKOW NIETOPERZY \\ ZIMUJĄCYCH W WAPIENNYCH SZTOLNIACH
}

\section{Wincenty HARMATA}

Harmata W., 1987: The frequency of winter sleep interruptions in two species of bats hibernating in limestone tunnels. Acta theriol., 32,

In several small limestone tunnels near Cracow $\left(50^{\circ} 02^{\prime} \mathrm{N}, 19^{\circ} 52^{\prime} \mathrm{E}\right)$ it was found that on average Rhinolophus hipposideros awaken every 17.8 days, and Myotis myotis 41.2 days.

[Institute of Environmental Biology, Jagiellonian University, ul. Karasia $6,30-060$ Kraków, Poland]

It is widely accepted that hibernation in bats of the temperate zone is normally interruped from time to time for reasons yet unknown. The aim of this report is to determine frequency of such interruptions in two bat species: Rhinolophus hipposideros (Bechstein, 1806) and Myotis myotis (Borkhausen, 1797) wintering in man-made limestone tunnels.

During 1956-1983 period the frequency of awakening was observed in bats hibernating in several small limestone tunnels made during the First World War period near Cracow $\left(50^{\circ} 22^{\prime} \mathrm{N}, 19^{\circ} 52^{\prime} \mathrm{E}\right)$. The largest of ten tunnels has a lenght of $70 \mathrm{~m}$, the smallest - $15 \mathrm{~m}$. The height of underground passages ranged from 3 to $5 \mathrm{~m}$, the width -2 to $10 \mathrm{~m}$. In the parts of tunnels close to their entrances, the temperature in winter months ranged from $-4^{\circ}$ to $0^{\circ} \mathrm{C}$ while in their deepest parts it reached $10^{\circ} \mathrm{C}$ with humidity of $80-90 \%$. Daylight penetrated only the parts closest to the entrances. The tunnels were visited in 3 to 5 -day intervals. The exact position of each bat was registered without disturbing the animal. The duration of uninterrupted stay at particular position and intervals at which the animal shifted to other places were noted.

The average length of uninterrupted winter sleep in $R$. hipposideros was 17.8 days, $\mathrm{SD}=5.2, \mathrm{SE}=0.98$ (the number of individuals observed $n=141$ ). The longest period without awakening was 86 days, the shortest - 2 days. In $M$. myotis the average length of uninterrupted sleep was 41.2 days, $\mathrm{SD}=5.92, \mathrm{SE}=0.54(n=55)$. The longest uninterrupted sleep lasted for 98 days, the sortest $\longrightarrow 5$ days. The longest spells of uninterrupted sleep occurred in both species in the middle of winter i.e. between December and February. The bats inhabited tunnels from the beginning of October till the end of April. R. hipposideros were hibernating within temperature range from 2 to $10^{\circ} \mathrm{C}$ while $M$. myotis - from $-4^{\circ}$ to $10^{\circ} \mathrm{C}$.

Hooper \& Hooper (1956) found that R. hipposideros in England awake at average 7 to 14-days intervals which partially agrees with the above 
results. In some Dutch localities however, $M$. myotis awakened more frequently than $R$. hipposideros (Dean \& Wichers, 1968). Also there, Myotis daubentoni (Kuhl, 1819) is reported to awake more frequently than R. hipposideros and M. myotis (Dean. 1960). Yet another data provided from Slovakian caves (Rybar, 1975) indicate that $M$. myotis there awaken, on average, every 45 days. This figure agrees well with my observations. The above authors report that $R$. hipposideros and Myotis emerginatus awaken infrequently.

It was shown that $R$. hipposideros awakened more frequently and assume àctive behaviour faster than $M$. myotis (Harmata, 1985). The thermal preferendum for $R$. hipposideros in natural and laboratory conditions fell over higher temperatures than that in M. myotis (Harmata, $1969 ; 1973)$. In contrast to $M$. myotis, $R$. hipposideros avoid cooler places for hibernation (Ancieux, 1948); this may facilitate more frequent awakening. All the above information points at linkage between the frequency of awakening and thermal preferendum.

\section{REFERENCES}

Ancieaux F., 1948: Le sommeil hivernal des nos Chiroptéres d'aprés des observations locales. Bull. Mus. roy. Hist. nat. Belgique, 24: 1-27. - Daan S., 1969: Frequency of displacements as a measure of activity of hibernating bats. Lynx, 10: 13-17. - Daan S. \& Wichers H. J., 1968: Habitat selection of bats hibernating in a limestone cave. Z. Säugetierk., 33: 262-287. - Harmata W., 1969: The thermopreferendum of some species of bats (Chiroptera). Acta theriol., 14: 49-62. Harmata W., 1973: The thermopreferendum of some species of bats (Chiroptera) in natural conditions. Zesz. Nauk. UJ, 19: 127-141. - Harmata W., 1985: The length of awakening time from hibernation of three species of bats. Acta theriol., 30: 321-323. - Hooper J. H. D. \& Hooper W. M., 1956: Habits and movements of cave dwelling bats in Devonshire. Proc. Zool. Soc. London, 127: 1-26. Rybař P., 1975: Pevnost Bouda - nárh chráněného zimoviště netopýrů. Pr. Stud. Př́r., Pardubice, 6-7: 175-199.

Received 26 May 1986, Accepted 25 June 1986.

PANSTWOWE WYDAWNICTWO NAUKOWE 2 WARSZAWA

Nakład $885+90$ egz. Obj. ark. wyd. 15. Maszynopis otrzymano 06.04.1987 r. Podpisano do druku w grudniu $1987 \mathrm{r}$. Druk ukończono w lutym 1988 r. Papier druk. sat III kl. 80 g. 